\title{
LAGMANDSELEMENTET INDEN FOR DEN SAMLEDE KRIMINALPOLITIK
}

Af fangselsinspektør, lic. Jur. Ole Ingstrup, Kragskovhede

Det emne, som jeg har fået opgivet for dette foredrag, har jeg set som udtryk for et ønske om at starte en drøftelse af den ikke-professionelle borgers forhold til de forskellige led i den lange kriminalpolitiske kæde, der går fra lovgivningen via politiets aktiviteter og domstolenes arbejde til den fuldbyrdende sektor, og som et ønske om at tilvejebringe et grundlag for debatten om hensigtsmæssigheden af og muligheden for en øget kontakt mellem offentligheden og det samlede kriminalpolitiske mønsters enkelte led.

Det forekommer mig ikke overraskende, at en sådan drøftelse er fundet ønskelig, men det er glædeligt overraskende, at man i Norden så tidligt har fået interesse for denne problemkreds.

I andre lande - særligt i U.S.A. og Canada - har drøftelsen af dette emne været levende i adskillige år, men det er min fornemmelse, at emnets aktualitet $\mathrm{i}$ disse lande $\mathrm{i}$ betydeligt omfang har beroet på, at man i disse lande har følt - eller erkendt - at det kriminalpolitiske har været kriseramt.

Man har i disse lande søgt at opnå eller genopnå ro og stabilitet omkring kriminalpolitikken ved at etablere en nærmere kontakt mellem den brede offentlighed og de kriminalpolitiske beslutningstagere.

Når jeg antyder, at de nordiske lande er tidligt fremme med denne vigtige debat, ligger der heri en antydning af, at det efter min mening ville være en klar overdrivelse at sige, at den nordiske kriminalpolitik og de nordiske strafferetssystemer skulle befinde sig i en krisesituation eller blot noget, der minder om en krisesituation. Vi befinder os i en vanskelig tilpasningssituation, men krise er efter mine begreber noget ganske andet.

På det kriminalpolitiske område bør man som alle andre steder vælge sin terminologi med omhu. Overdrivelser kan - som jeg skal vende tilbage til føre til uheldige, utilsigtede virkninger.

Jeg finder det overordentligt glædeligt, at man tidligt har fået blik for den problemkreds, som der her er tale om, idet det giver os mulighed for at betragte »udviklingen " som noget, man styrer, i stedet for et fænomen man bestandigt jagter, og hvis uberegnelige krav man ser sig nødsaget til at opfylde, så vidt det lader sig gøre.

Hvad nu forst angår hensigtsmæssigheden af offentlighedens eller det læge elements inddragelse i vor fremtidige kriminalpolitik, er det min opfattelse, at en sådan inddragelse ikke alene er hensigtsmæssig, men direkte nødvendig både ud fra et økonomisk og ud fra et ideologisk eller forståelsesmæssigt synspunkt. 
Den økonomiske situation inden for vort geografiske område, influeret på afgørende måde af den internationale, økonomiske udvikling, giver os gode grunde til at formode, at der i de kommende mange år ikke vil være mulighed for betydelig øget aktivitet inden for den kriminalpolitiske sektor i videste forstand. Sandsynligvis vil det oven i købet komme til at forholde sig således, at kriminalpolitikken og dens praktiske forgreninger vil kunne imødese dårligere økonomiske vilkår, end når talen er om andre offentlige sektorer som for eksempel undervisnings- og social- og sundhedssektoren.

Der er næppe tvivl om, at det vil være lettere at opnå ressourcetildeling på områder, der er i stand til at definere sig med let forståelige, positive mål, end det vil være tilfældet med den straffende sektor med sine i sit grundlag negative mål.

Straffesektoren ses langt mindre som et naturligt omkostningskrævende serviceelement i det velfungerende samfund, end det er tilfældet, for så vidt angår så mange andre dele af den offentlige virksomhed.

Hertil kommer, at lande som de nordiske, hvor know-how er et af de betydeligste »råstoffer«, og hvor højt udviklet teknologi er et særkende for industriens produkter, antagelig vil komme til at opleve en udvikling med stadig større forskelle i omkostningsstrukturen, hvis man sammenligner det offentliges og erhvervslivets forhold.

I erhvervslivet vil lønandelen komme til at udgøre en stadig mindre del af den samlede omkostningsmængde, idet der er grund til at tro, at produktudvikling og forfinet teknik vil lægge beslag på en stadig mere dominerende del af omkostningerne. Selv kraftige lønstigninger vil formentlig ikke influere på dette forhold.

I den offentlige sektor vil situationen være en anden. I denne sektor vil udgifterne til personalet, hvis lønforhold vil være afhængige af udviklingen i erhvervslivets lønforhold, komme til at udgøre en bestandig mere dominerende post blandt omkostningerne som helhed. - Dette gælder ikke mindst i vore landes fuldbyrdelsessektor.

Hvis disse antagelser er rigtige, forudser jeg, at den eneste mulighed for udvidelse og forbedring af straffesektorens aktivitetsniveau må komme til at gå gennem metode- og strukturomlægninger eller - og gerne samtidig gennem tilførsel af ressourcer, der ikke samtidig forøger omkostningerne eller kun forøger dem i stærkt begrænset omfang.

Skal en sådan ressourceforøgelse finde sted uden nævneværdig omkostningsforøgelse, ligger der efter mit skøn i offentligheden eller det læge element ganske betragtelige muligheder, som hidtil kun i stærkt begrænset udstrækning har været udnyttet i Norden.

På det ideologiske eller forståelsesmæssige område er det formentlig rimeligt at antage, at det kriminalpolitiske felt ikke alene påkalder sig en ret betydelig offentlig interesse, men tillige er et felt, som de fleste mener at have forstand på. 
I denne forbindelse er det næppe nogen overdrivelse at antage, at en stor gruppe af befolkningen mener, at uønsket adfærd bedst bekæmpes gennem strafsanktionerede forbud. Det ligger nok dybt i den almindelige befolkning at antage, at kriminalitet begås efter en rationel afvejelse af gerningsmandens ønske om at foretage en kriminel handling over for navnlig tyngden af den straf, han eventuelt vil blive idømt ved at foretage handlingen.

Hvis denne iagttagelse er rigtig, er der grund til at tro, at samfundets øgede kompleksitet vil føre til et ønske om en betydelig udvidelse af antallet af straffebud, og der er ligeledes grund til at forvente, at den næsten uafbrudte stigning $\mathrm{i}$ antallet af anmeldte forbrydelser vil føre til, at borgeren med stadig større styrke vil stille krav om, at længere og strengere straffe bliver bragt i anvendelse.

Hvis den økonomiske stramning, som vi har oplevet de seneste år, fortsætter, er der vel gode grunde til at tro, at tendenserne i retning af strafferetlig stramning vil forstærkes.

De nordiske landes kriminalpolitik i de senere år har imidlertid været karakteriseret ved helt modsatte tendenser i forhold til, hvad der er anført ovenfor. - Man har haft et ganske klart ønske om at gennemføre af- og nedkriminalisering, og man har i begrænset omfang gjort forsøg på at finde andre og nye muligheder end straf til at begrænse uønsket adfærd.

$\mathrm{P} a ̊$ denne baggrund er det vel rimeligt at mene, at hvis man ønsker lægmanden inddraget i den kriminalpolitiske diskussion som en ligeværdig partner, må der fra systemets side udfoldes alvorlige bestræbelser for at bibringe ham et bedre beslutningsgrundlag, end han for øjeblikket har, således at han kan tage stilling på et rimeligt nuanceret grundlag.

Der må ikke i det netop sagte lægges nogen stillingtagen til spørgsmålet om »en eller den offentlige mening « som en definitiv størrelse, thi herom ved vi endnu alt for lidt.

Jeg ser det blot som en mulighed, at der i det lidt længere løb vil opstå et spændingsforhold mellem lægmanden og straffesystemets professionelle med indbygget mulighed for en kriseagtig udvikling, som en del andre lande har set det, såfremt den almindelige borger ikke informeres på tilstrækkeligt seriøst grundlag.

Det er imidlertid højst tvivlsomt, hvorledes man etablerer et bedre beslutningsgrundlag for den ikke-professionelle i den kriminalpolitiske diskussion.

Forskningen på dette vanskelige område er endnu ikke så omfattende og udviklet, at der er mulighed for at drage praktisk nytte af den. Definitoriske og metodemæssige problemer synes på dette felt at være dominerende. En ganske god illustration herpå var Europarådets 13. kriminologiske konference (november 1978).

Spredt i litteraturen finder man dog indikationer for, at en bred og grundig information og navnlig et nærmere kendskab til lovovertrædere har en 
angstdæmpende funktion i forhold til kriminalitet. Der synes altså at være en vis støtte for den antagelse, at medinddragelse af lægfolk i straffesystemet skulle kunne øge muligheden for at nå en mere nøgtern vurdering af den samlede kriminalpolitik, end det vil være tilfældet uden en sådan medinddragning af befolkningen eller dele af den.

Efter min mening er der altså både økonomiske og ideologiske forhold, der i meget høj grad taler for at inddrage lægfolk i det strafferetlige arbejde $i$ en langt videre udstrækning, end det for tiden er tilfældet $i$ de nordiske lande, men hertil kommer, at det næppe kan afvises, at lægfolk under mange forhold - eventuelt og ofte $i$ et samarbejde med professionelle $i$ straffesystemet- vil have bedre muligheder for at løse eksisterende problemer, end det vil være tilfældet med et system alene bestående af professionelle udøvere.

En ting er imidlertid at nå til en erkendelse af nødvendigheden af at inddrage lægfolk i det strafferetlige system; en ganske anden og mere kompliceret ting er det at anvise farbare veje til realiseringen af et sådant mål.

Hvis man - som jeg - tror på, at der er ganske gode muligheder for at udnytte forskningens resultater ved at omsætte forskningen til hensigtsmæssige, praktiske resultater, kan der være mening i at anspore og opmuntre forskerne til at se på dette område med større intensitet, end det for øjeblikket er tilfældet.

En canadisk forsker udtalte for nogen tid siden i tidsskriftet »Justice et Public«, at i Californien - og andre amerikanske stater - nægter borgerne at betale skat. - De hævder, at de ydelser, de modtager til gengæld for at betale til det offentlige, ikke står i et rimeligt forhold til hinanden. $\mathrm{Og}$ han fortsætter herefter med at sige: „Det er under sådanne forhold på tide, at offentlighedens adfærd undergives forskning."

Jeg deler ikke denne opfattelse.

Efter min mening har man under sådanne forhold set fra en praktisk synsvinkel ingen eller kun ringe glæde af forskningen. - Under sådanne forhold hjælper kun handling. - Men som nævnt tidligere anser jeg ikke de nordiske landes straffesystemer for at være i nogen form for krisesituation, således som man med en vis berettigelse vil kunne sige det om visse dele af de amerikanske straffesystemer, og der er derfor for vort vedkommende tid til at foretage forskning i betydeligt omfang og samtidig behov for den, inden vore systemer muligvis nærmer sig en krisepræget situation.

For at udbygge kontakten mellem praktikere og forskere på det kriminalpolitiske område i Danmark har justitsministeriet nedsat et permanent kriminalpolitisk forskningsudvalg, hvori der foregår en omfattende gensidig orientering mellem praktikere og forskere, og det forekommer ganske utvivlsomt, at dette udvalg i høj grad er med til at stimulere forskeres lyst til at beskæftige sig med områder, der ikke blot er af forskningsmæssig betydning, men tillige af praktisk, kriminalpolitisk relevans. - At også mini- 
steriet tillægger udvalget stor betydning, ses blandt andet deraf, at departementschefen er formand for udvalget.

Jeg betragter dette organ eller tilsvarende organer som særdeles velegnede til at henlede forskernes opmærksomhed på betydningen af at udvide forskningsaktiviteterne omkring forholdet mellem lægfolk og den kriminalpolitiske praksis.

Hvis man vender sig mod den mere direkte forbindelse mellem straffesystemet og lægfolk, er det vel næsten trivielt at understrege betydningen af løbende, pålidelig og letforståelig information og betydningen af et mangegrenet informationsnet $\mathrm{i}$ forhold til massemedierne som formidlere til offentligheden. - Visse anvisninger på et forbedret forhold mellem den fuldbyrdende sektor og massemedierne i Danmark blev givet i betænkningen »Kriminalforsorgen og massemedierne« (1974).

Den åbenhed, som heri blev anbefalet, bør imidlertid ikke blot herske i forholdet mellem den straffuldbyrdende sektor og massemedierne, men bør udstrækkes til at gælde hele straffesystemets forhold til medierne.

Det er min opfattelse, at der er et betydeligt behov for, at domstolene stræber mod en øget information af massemedierne, navnlig derved, at der gives information på et mere generelt niveau, end det for tiden er tilfældet. Der er formentlig i langt højere grad grund til at koncentrere domstolenes informationsvirksomhed om »praksis« på forskellige, centrale felter, end der - som jeg fornemmer, det oftest er tilfældet for tiden - er grund til at kommentere enkelttilfælde, der af den ene eller den anden grund har påkaldt sig mediernes opmærksomhed, men en sådan omlægning af informationsniveauet kræver en mere offensiv holdning til pressen, end det hidtil synes at have været tilfældet, at domstolene har haft.

Norden er formentlig et af de områder, hvor man i ringest udstrækning gør brug af lægfolk i den offentlige sektor, og under alle omstændigheder synes dette at være tilfældet, når man tænker på det strafferetlige område. - Anvendelsen af lægfolk på dette område er langt mere udbredt i lande som for eksempel U.S.A., England og Canada, og ikke mindst i det (for os) Fjerne Østen gøres der brug af lægfolk i straffesystemet i en særdeles udstrakt grad. - De årlige rapporter fra UNAFEI (United Nations Asia and Far East Institute for the Prevention of Crime and Treatment of Offenders) i Japan viser dette ganske tydeligt.

I vore lande vil en øget medvirken af lægfolk imidlertid nok støde på i det mindste to sæt af vanskeligheder:

For det første forekommer de nordiske lande mig at være gennemsyret af det, jeg vil kalde en »skatteyder-mentalitet«, hvis hovedtræk det er, at befolkningen afviser at tage sig af de samfundsmæssige problemer under henvisning til, at den løfter en betydelig skattebyrde og derfor må forvente, at »systemet« tager sig af den slags problemer, som ikke mindst det strafferetlige område er karakteriseret ved. 
For det andet vil en øget integration af lægfolk i det straffende område formentlig støde på væsentlige modforestillinger hos vore egne medarbejdere. Man kunne fristes til at mene, at en sådan modvilje mod at inddrage lægfolk i arbejdet med kriminalitetsproblemer kunne begrundes med fagforeningssynspunkter, understøttet af den eksisterende arbejdsløshed, men der er for mig ingen tvivl om, at det i langt højere grad er, hvad man kunne kalde faglige synspunkter, som skaber den omtalte modvilje. Medarbejderne - ikke mindst socialrådgiverne - i vort system er af den formening, at den læge befolknings inddragelse i arbejdet med kriminalitetsproblemer vil skabe flere problemer for dem, end det vil løse. - Og i en længere overgangsperiode kan man bestemt ikke afvise, at dette synspunkt er det rette.

Som et eksempel fra den danske arena kan man pege på forslaget om at indføre kontaktmænd i kriminalforsorgen, hvor forslaget gik ud på at supplere den professionelle socialrådgiverbistand, som tilbydes prøveløsladte og betinget dømte under tilsyn, med en kontakt til en læg person, som kunne accepteres af den domfældte, og som geografisk befandt sig i dennes umiddelbare nærhed.

Mod dette forslag har der været en ret betydelig modstand i kredsen af professionelle medarbejdere, idet man navnlig har peget på vanskelighederne ved at rekruttere sådanne kontaktmænd og samtidig har peget på, at klientudpegede kontaktmænd formentlig vil være af tvivlsom bistand for de professionelle medarbejdere.

Det er muligt, at medarbejderorganisationerne har ret i deres antagelser, men det er også en mulighed, at medarbejderne reagerer med en frygt over for det usikre.

Under alle omstændigheder anser jeg det for at være en central opgave at søge at opnå medarbejdernes accept af og forståelse for, at inddragelse af det læge element i det straffende system ikke først og fremmest vil betyde et konkurrenceelement, men i langt højere grad vil åbne muligheder, som hidtil har været uprøvede.

Man må imidlertid ikke undervurdere den modnelsesproces, som er helt nødvendig i medarbejderkredsen, før en bredere inddragelse af det læge element kan finde sted i det strafferetlige system, og det bør navnlig understreges, at det læge element ikke søges inddraget på bekostning af de professionelle medarbejdere, men som et supplement til disses virksomhed.

En sådan udvikling er ganske besværlig, og den er navnlig efter mit skøn meget besværliggjort af den unuancerede og sjuskede måde, hvorpå den såkaldte neo-klassicisme er blevet præsenteret på. - Der er i denne forbindelse talt meget om, hvor lidt det hjælper at gøre noget for mennesker, og hvor latterligt det er at tro på nogen form for behandlingstanke. Men dels har man ikke gjort sig umage med at definere, hvad behandling er eller blot at antyde det, dels har man i ophøjet filosofisk selvglæde sat sig ud 
over de praktiske implikationer, som glæden over den såkaldte behandlingsideologis død har ført med sig.

Navnlig har man ikke set, at der kunne være noget positivt i at gøre noget for mennesker, der blev indespærret, af andre end behandlingsmæssige grunde.

Den slagordsmæssige karakter, som den bredere neo-klassicistiske debat har haft, hvor udtalelser som »behandlingsideologien er død « og »vi tror ikke længere på behandling af kriminelle « har floreret, har efter min mening været stærkt medvirkende til en uheldigt udbredt opfattelse $\mathrm{i}$ vide personalekredse af, at personalets opgave alene er at gennemføre en strafs fuldbyrdelse og - og det er det afgørende- intet herudover.

De faktiske forhold stemmer da heldigvis også kun dårligt sammen med de nyere tiders slagord:

I Danmark afgav Planlægningsudvalget en ret omfattende betænkning indeholdende forslag, der sigter mod en mere effektiv social indsats dels over for de indsatte, dels over for den klientgruppe, der hører til kriminalforsorgen i frihed. Antallet af forsorgsmedarbejdere blev stærkt øget i 1970 'erne, og i samme periode gennemførtes i den danske kriminalforsorg et betydeligt uddannelsesprogram. Endelig gennemførte man en lang række af eksperimenter i statsfængslet i Ringe i forbindelse med denne institutions etablering. - En lang række af tilsvarende eksempler kan nævnes fra de øvrige nordiske lande.

Fælles for de nævnte eksempler er det, at de hviler på den grundopfattelse, at det nytter at gøre noget for de mennesker, der på grund af kriminalitet er undergivet kriminalforsorg i den ene eller den anden form. - I den forstand er behandlingsideologien altså ikke død, og hvis man ser det som en afgørende forudsætning for etablering af et frugtbart samarbejde mellem de professionelle medarbejdere og lægfolk, at de professionelle bevarer troen på eget værd, er det nødvendigt, at den debat om behandlingsideologien, som blandt andet de såkaldte neo-klassiske tanker har intensiveret, gøres mere nuanceret og navnlig mere nuanceret $\mathrm{i}$ forhold til de opgaver og arbejdsvilkår, som under snart sagt en hvilken som helst herskende filosofi på det strafferetlige - herunder straffuldbyrdende - område påhviler områdets ansatte.

I denne forbindelse bor det heller ikke overses, at der gennem straffesystemets personale strømmer en betydelig mængde af information ud til den læge befolkning og at karakteren af denne information i meget betydelig grad er afhængig af den måde, hvorpå personalets opgaver anskues fra mere teoretisk side.

Brugen af lægfolk i straffesystemet er givetvis langt mere udbredt i U.S.A., hvorfra man vil kunne hente en betydelig inspiration og drage nytte af en betydelig erfaring.

Man får et godt indtryk af det omfang, hvori lægfolk anvendes i det 
amerikanske straffesystem, ved at læse rapporten »Community Grime Prevention«, som The National Advisory Commission on Criminal Justice Standards and Goals udsendte i 1973.

I denne rapport antager man, at der findes omkring 100.000 ikke-offentlige foretagender, der er aktive inden for det samlede kriminalpolitiske område.

Enkelte eksempler skal nævnes til illustration:

The Fortune Society med hovedkvarter i New York er en meget betydende organisation, der beskæftiger professionelle medarbejdere, frivillig arbejdskraft og tidligere kriminelle $\mathrm{i}$ et vist omfang, og som ud over at beskæftige sig med betinget dømte og prøveløsladtes problemer virker på mere generelt niveau typisk som medlem af rådgivende udvalg for New York City's bystyre og som konsulenter i særlige forhold, der har sammenhæng med kriminalitet og kriminalpræventivt arbejde. Herunder udfolder organisationen betydelige bestræbelser for gennem afholdelse af møder med lægfolk at informere om den førte og den tilstræbte kriminalpolitik.

Det er ikke alene gennem organisationens eget blad »The Fortune News«, man får indtryk af organisationens indflydelse og betydning, men i mindst lige så høj grad gennem den amerikanske dagspresse, som synes at ofre foretagendet en betydelig interesse.

New Jersey Automobile Dealers Association har etableret et træningsprogram for unge kriminelle med henblik på at uddanne dem inden for automobilbranchen som reparatører eller lignende. - Organisationen tæller cirka 80 procent af statens mere end 1.000 automobilforhandlervirksomheder, men har foreløbig koncentreret det omtalte program til at omfatte løsladte fra et bestemt fængsel i staten. New Jersey Department of Institutions and Agencies, som følger projektet - der betales af det amerikanske arbejdsministerium - har givet udtryk for, at der synes at være betydelige muligheder for en fremtidig udstrækning af ordningen til at omfatte andre fængsler end det, som allerede er omfattet af projektet.

Chicago Metropolitan Correctional Center har et ret omfattende undervisningsprogram for et stort antal af institutionens indsatte. Dette undervisningsprogram gennemføres ved hjælp af en heltidsansat undervisningsleder, der engagerer frivilligt, udefra kommende - oftest professionelt personale til at varetage undervisningen af de indsatte. - Ofte er engagementet kortvarigt - fra to til seks måneder - for den enkelte »volunteer «, men dels muliggør dette en betydelig variation i undervisningstilbudene, dels er sådanne kortvarige arrangementer lettere overskuelige for den enkelte medvirkende, end det ville være tilfældet, hvis der var tale om længere perioder. -. For den, der besøger institutionen, virker dette program imponerende.

Mod den forsvarede hovedtanke kan det være rimeligt at indvende, at man netop i U.S.A. har et godt eksempel på, at en kriminalpolitisk krise 
kan udvikles side om side med en udstrakt og traditionsfast brug af frivillig lægmandsindsats på mange af straffesystemets områder.

Man må imidlertid betænke, at det amerikanske samfund på snart sagt alle områder er langt mere komplekst og inhomogent, end det er tilfældet i de nordiske samfund, og at kriminalitetsbilledet - måske som en følge heraf - er langt mere dystert end det nordiske kriminalitetsbillede, og jeg ser i disse afgørende forskelle en mulighed for, at et lægmandsarrangement specielt i vore straffuldbyrdelsessystemer vil rumme en mulighed for at influere på den kriminalpolitiske udvikling i langt højere grad i Norden, end det for eksempel har været tilfældet i U.S.A.

Selvom man imidlertid er af den opfattelse, at inddragelse af lægfolk i det kriminalpolitiske arbejde vil medvirke til at undgå, at området bliver kriseramt, står der et betydeligt planlægningsarbejde tilbage, som tager sigte på at føre den meget generelle tanke ud i livet.

Sagt meget $\mathrm{i}$ almindelighed må man nok sige, at et sådant samarbejde mellem lægfolk og det strafferetlige system bør tage sigte på at gøre behovene for det læge elements indsats tilstrækkeligt klare og konkrete til, at de kan appellere til den almindelige befolknings lyst til at gøre en indsats på dette område. - $\mathrm{Og}$ herudover må man nok udfolde betydelige bestræbelser for at gøre vejene til en aktiv indsats fra lægfolkenes side tilstrækkeligt korte og let farbare til, at en indsats fremtræder som tillokkende for denne del af befolkningen.

Der kan næppe være tvivl om, at det svenske samarbejde mellem arbejdsmarkedets parter og Kriminalvården er en måde at løse dele af dette problem på. - Et tilsvarende samarbejde er i et vist omfang etableret i Danmark, men helt effektivt bliver samarbejdet nok først, når det får virkninger ude $\mathrm{i}$ de enkelte lokalområder, og når de enkelte virksomheder inddrages i arbejdet. - Når social ansvarlighed i denne specifikke retning bliver et delmål for mange virksomheder.

Selvom det foreliggende oplæg kun berører dele af overskriftens område, har overvejelserne omkring disse forhold gjort det klart, at behovet for øget lægmandsdeltagelse ikke alene er åbenbart og påtrængende, men tillige, at det nødvendige forberedelsesarbejde både i forholdet indadtil til det strafferetlige system og i forholdet udadtil til forskere, organisationer og enkeltindivider vil være så omfattende og tidkrævende, hvis det skal udføres med den fornødne omhu, at en igangsætning af det forberedende og planlæggende arbejde ikke bør lade vente længe på sig.

I 1970 'erne koncentrerede den kriminalpolitiske debat sig i betydelig udstrækning om at nedbringe antallet af frihedsberøvede personer indenfor det strafferetlige område. Man fik således betænkningen om nogle af- og nedkriminaliseringsspørgsmål i Danmark, og det for Danmarks vedkommende betydningsfulde straffelovråd overvejede adskillige muligheder for en æendret vurdering af centrale strafferetlige problemer. Der udfoldedes 
betydelige bestræbelser i hele Norden for at bevæge sig frem mod en mindre fangebefolkning, og navnlig frem imod en mere tidssvarende afgrænset fangebefolkning.

Samtidig var interessen i 1970 'erne betydelig for at skabe mere tidssvarende forhold for de indsatte og for - delvis derigennem - at skabe bedre retsgarantier for de indsatte under deres afsoningsperiode.

Disse bestræbelser har givet sig meget betydelige praktiske udslag, og perioden må betragtes som særdeles givende.

Det er mit hảb, at i det mindste dele af 1980'erne vil blive præget af overvejelser af, hvorledes man kan inddrage lægfolk i den kriminalpolitiske debat, og i det man kunne kalde den kriminalpolitiske praksis.

Ole Ingstrup 